spring and of nests and workers in summer is so common that I am tempted to think that the more conspicuous, and therefore more often caught, queens are infertile, and the rewards for their destruction wasted. Perhaps some member of the Association of Economic Biologists will take the matter up?

Alfred O. Walker.

\section{Ulcombe, Kent.}

IN reference to the letter of $\mathrm{Mr}$. H. V. Davis (NATURE, October 12, p. I09), I may say that in this district ordinary wasps have been decidedly scarce this year. Reports from several other localities are of the same character. Queens, however, were abudant in the spring (May and June), but I think that only a few survived the wet and cloudy weather.

I make a point of cultivating these insects, as they are extremely interesting to watch, and destroy myriads of flies every summer. There were six embryo nests in my garden in May last, but only one (Vespa vulgaris) managed to withstand the vicissitudes of the inclement weather. This nest was a weak one, for when I dug it out on September. 20 it consisted of four layers of cells, the top one alone being for small working wasps. (rooo cells), while the others were exclusively for queens and drones (1450 cells). This proportion is quite exceptional according to my own observation, for I have commonly found the smaller cells greatly in excess of the others. In a much stronger nest (Vespa germanica) which I itook here on October 6 , I9I5, there were 12,900 cells, forming ten tiers, and less than a quarter of the former had been devoted to the rearing of queens and drones.

Very few persons will be inclined to attract wasps to reside in their own immediate neighbourhood, but anyone caring to study these insects should make a few little cavities in dry situations early in April. The queens begin selecting eligible positions in that month (average date, April 17). It is certain that wasps are not so aggressive and violent as commonly supposed. They display remarkable industry and activity, for at midsummer they may be observed streaming to and from their homes during a long working day of eighteen hours! In view of the justified agitation against the house-fly in recent years, it is questionable whether the usual spring campaigns against queen wasps shoùld be encouraged. On a bright summer day in roI3 I carefully watched the entrance of a wasps' nest in my garden, and concluded that the insects brought home at least 2000 flies.

44 Egerton Road, Bristol, October I4.

W. F. Denning.

Referring to Mr. H. V. Davis's letter in Nature of October 12 on the scarcity of wasps, I have taken nests for some years over an area a little less than rooo acres as follows:-1906, 95 nests; 1907, 6r; 1908, 3I; 1909, II3; I9ro, one (Vespa rufa, Linn.); х911, 85 ; 1912, 56 ; I9I3, I89; 1914, 21 ; I915, 56 .

I916: I knew of three Vespa vulgaris, Linn., nests, and took one as it hindered ploughing, and in the early part of the season I hived three Vespa sylvestris, Scop., nests as there were a very large number of $V$. sylvestris queens about. My hived ones died out before hatching queens (this wasp is always earlier here, and gone before the fruit, and I have never caught it in my house), as did some unhandled nest I heard of. In IgIo the $V$. rufa nest had been scratched up before I got it, and I saw a few $\nabla$. vulgaris workers about the Severn, indicating at least one nest, but actually saw no other nests that year.

Longner Hall, Salop, October I7. NO. 2452, VOL. 98]
The Dartford Naturalists' Field Club this season also experienced a scarcity of wasps; local papers reported the same about Gravesend on the east, and Bexley on the west.

Their nests were very plentiful last year, and so queens were exceedingly plentiful in spring-abnormally so. But later a cold spell nipped those about at the time.

Observers here speak confidently of the persistent hunting of flies by these early queen wasps, out too soon for nectar from flowers, and say the early wasps put down the flies for this summer. Flies were far more numerous last year, and, other things being equal, a beekeeper predicts many flies next summer, because of this season's scarcity of wasps. He remembers such an experience at Green St. Green (Dartford).

On May 27 I saw a note about more wasps than usual at Dudley, a district fairly free compared with the south and west. It was during May when so many early queens were observed here.

$$
\text { S. PRIEST }
$$

(Hon. sec., Dartford Naturalists' Field Club).

ReFerRing to Mr. Davis's letter, it would be interest. ing to know if the same dearth of wasps has been noted in the cider counties.

I have caught only two here this season (in jars of beer and sugar placed outside), while last year I trapped hundreds.

Strawberry Hill, Middlesex, October ${ }_{13}$.

\section{Glacial Nomenclature and Scott's Antarctic Expedition.}

IN the review of my book, "With Scott-The Silver Lining," in NATURE of June I, the reviewer, among many kindly remarks, takes exception to my use of the word "riegel." He prefers the English word "bar." I have briefly explained my point of view in the Geographical Journal (p. 57I, December, 1914), but may be allowed to elaborate it a little.

Webster gives fourteen paragraphs dealing with different meanings of the word "bar." One at least of these-the bar of a river-is a geographic term. Why should the reviewer use the Scotch word "corrie" or the French "cirque" (as I use the Welsh "cwm") if not because-as in my case-there is no English word which is not ambiguous? I believe that there was a movement in Oxford to standardise geographic nomenclature. I sent in a memorandum in 1913 , but have heard nothing of it lately.

May I refer briefly to further Antarctic questions raised in the review? The "catenary curves" illustrated in my book are not "ordinary denudation curves" in my opinion. They are common in the Alps (e.g. above Hospenthal, on the St. Gothard Road), but not in regions of normal erosion. An ordinary water-cut valley only a few hundred yards across would certainly not exhibit the smooth catenary curve of the small empty Antarctic valleys.

The small scale of the photograph of the Discovery Hut (p. 189) has, I feel sure, led the reviewer into a natural error. My colleague, Debenham, is emerging vid the window, since the door alongside was then blocked by ice. I am certain that Prof. J W. Gregory's hut could not have been satisfactorily erected so that the "support" shown in the figure could have been sunk in the ice. Under the latter condition the door sill would have been $3 \mathrm{ft}$. below ground-level.

The problem of the "origin of the glacier valleys" 